\title{
SISTEM INFORMASI KENAIKAN GAJI POKOK BERKALA (STUDI KASUS: STIKOM UYELINDO KUPANG)
}

\author{
Kornelia Ara Koli ${ }^{1}$ dan Donna Setiawati ${ }^{2}$
}

\begin{abstract}
Abstrak :
Penggajian merupakan salah satu proses dalam organisasi yang rentan terhadap masalah. Pengolahan data gaji yang lambat dapat mengakibatkan lambatnya dalam pembayaran gaji, sehingga akan mempengaruhi kinerja karyawan. STIKOM Uyelindo membutuhkan sistem penggajian yang mencakup sekaligus sistem yang dapat memberikan informasi secara otomatis mengenai kenaikan gaji pokok berkala. Gaji pokok berkala akan otomatis berubah berdasarkan masa kerja dan pendidikan terakhir. Hasil implementasi sistem baru ini dapat menghasilkan sistem informasi kenaikan gaji pokok berkala secara otomatis, sehingga mempermudah bagian keuangan untuk mengetahui dengan cepat karyawan yang mengalami perubahan gaji.
\end{abstract}

Kata Kunci : Sistem, Informasi, Gaji Pokok, Penggajian

\section{PENDAhULUAN}

STIKOM Uyelindo Kupang merupakan salah satu Perguruan Tinggi yang ada di Kota Kupang Provinsi Nusa Tenggara Timur dan dalam kegiatan administrasinya telah menggunakan teknologi informasi. Salah satu kegiatan administrasi yang telah menggunakan teknologi informasi adalah penggajian, hanya saja sistem yang lama ini masih memiliki kelemahan seperti belum adanya sistem kenaikan gaji pokok berkala secara otomatis. Kelemahan pada sistem lama itu mengakibatkan informasi kenaikan gaji pokok berkala yang diterima oleh karyawan seringkali mengalami keterlambatan. Sehingga misalnya seorang karyawan pada bulan Januari 2014 seharusnya mengalami kenaikan gaji pokok berkala, namun karena tidak adanya sistem informasi tentang masa kerja dan kenaikan gaji pokok berkala maka proses kenaikan gaji pokok berkalapun mengalami keterlambatan hingga beberapa bulan.
Gaji dan upah merupakan bagian dari kompensasi-kompensasi yang paling besar yang diberikan perusahaan sebagai balas jasa kepada karyawannya. Dan bagi karyawan ini merupakan nilai hak dari prestasi mereka, juga sebagai motivator dalam bekerja. Mulyadi (2001:373) mengemukakan bahwa gaji umumnya merupakan pembayaran atas penyerahan jasa yang dilakukan oleh karyawan yang mempunyai jenjang jabatan manajer, sedangkan upah umumnya merupakan pembayaran atas penyerahan jasa yang dilakukan oleh karyawan pelaksana (buruh). Umumnya gaji dibayarkan secara tetap perbulan, sedangkan upah dibayarkan berdasarkan hari kerja, jam kerja atau jumlah satuan produk yang dihasilkan. Sehingga dapat dikatakan bahwa masalah gaji atau upah ini sangat rentan jika tidak ditangani secara serius. Pembayaran gaji yang terlambat maupun kenaikan gaji berkala terlambat akan dapat berdampak pada kinerja karyawan. 
Keadaan seperti diatas seharusnya tidak terjadi jika lembaga mempunyai sistem informasi penggajian yang baik. Menurut Rahmat dan Ibrahim (2005) Sistem Informasi Manajemen (SIM) sebagai sistem yang menyediakan informasi yang digunakan untuk mendukung operasi, manajemen, serta pengambilan keputusan sebuah organisasi. SIM juga dikenal dengan ungkapan lainnya seperti: "Sistem Informasi". Sistem informasi penggajian dapat dirancang dan dibuat sesuai dengan kebutuhan lembaga. STIKOM Uyelindo Kupang membutuhkan sistem informasi penggajian yang tidak hanya mendata karyawan dan memproses penggajian saja namun lebih dari itu yaitu sistem yang memiliki alarm atau peringatan dini kenaikan gaji pokok berkala. Tentunya dengan adanya sistem otomatis ini akan membantu manajemen dalam hal ini pihak yayasan untuk mengambil keputusan dengan cepat dalam memberikan kenaikan gaji pokok pada karyawannya.

Kebutuhan akan sistem informasi penggajian ini didukung oleh penelitian sebelumnya yang dilakukan oleh Pramawanti (2003) yang melakukan penelitian membuat sistem penggajian dan pengupahan karyawan pada PT. Supersonic Chemical Industry di Gunungkidul. Peneliti lainnya yaitu Giyarti (2006) juga melakukan penelitian dengan membuat sistem penggajian pegawai pada Puslibang SDA Balai Sobo Yogyakarta.

Berdasarkan penjelasan diatas maka, permasalahan yang ditemukan adalah adanya kebutuhan mempunyai sistem informasi penggajian khususnya kenaikan gaji pokok berkala. Oleh karena itu tujuan dari penelitian ini adalah menghasilkan aplikasi pengolahan data-data penggajian khususnya data kenaikan gaji pokok berkala pada STIKOM Uyelindo Kupang.

\section{METODE PENELITIAN}

Penelitian ini dilakukan dengan beberapa tahapan. Pertama yaitu menyiapkan bahanbahan yang digunakan dalam merancang Sistem Informasi Kenaikan Gaji Pokok Berkala ini yaitu:

a. Dokumen-dokumen arsip (Data mengenai kepegawaian di ruang lingkup STIKOM Uyelindo Kupang).

b. Contoh-contoh formulir (berupa formulir ijin kerja karyawan, formulir absensi karyawan, dan slip gaji karyawan).

c. Laporan-laporan (laporan-laporan mengenai data Penggajian serta surat-surat penggajian lainnya)

d. Berbagai data yang didapat dari hasil observasi peneliti.

Bahan-bahan diatas diperoleh melalui cara pengumpulan bahan dan informasi dengan turun langsung ke lapangan atau ke objek penelitian dalam hal ini STIKOM Uyelindo Kupang serta melalui wawancara dengan pihak yang berkepentingan yaitu yayasan, bagian personalia dan bagian keuangan. Selanjutnya tahap kedua setelah menyiapkan bahan-bahan yaitu menganalisa sistem yang sedang berjalan. Hasil analisa merupakan usulan perbaikan atas sistem yang lama. Gambaran usulan sistem yang baru secara garis besar ditampilkan dalam bentuk bagan dokumen seperti terlihat pada gambar 1 . 


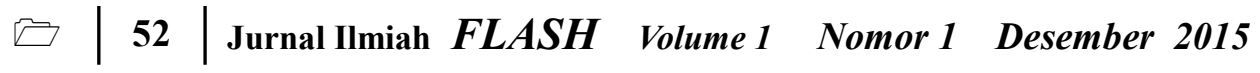

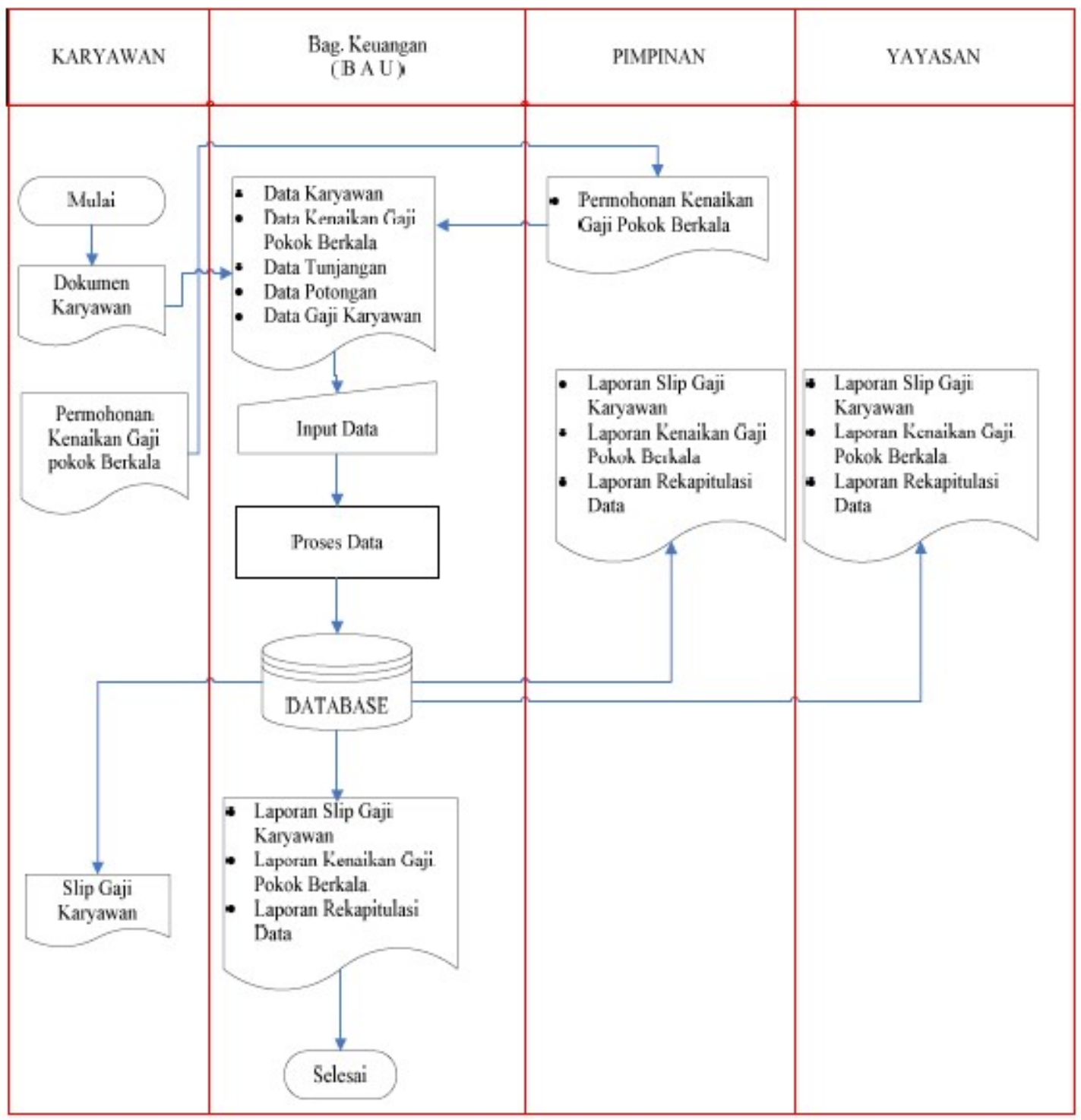

Gambar 1. Flowchart Dokumen

Pada Gambar 1 dapat dijelaskan bahwa karyawan memberikan dokumen karyawan berupa biodata lengkap ke bagian keuangan untuk selanjutnya dimasukkan dan di proses ke dalam database. Permohonan kenaikan gaji berkala diberikan ke pimpinan yang selanjutnya data tersebut diberikan ke bagian keuangan untuk diproses. Data-data yang sudah diproses kedalam database akan menghasilkan beberapa laporan seperti laporan slip gaji, laporan kenaikan gaji pokok berkala dan rekapitulasi data secara keseluruhan. Laporan-laporan tersebut diberikan ke pimpinan dan yayasan.

\section{HASIL DAN PEMBAHASAN}

Hasil implementasi dari sistem informasi penggajian ini adalah tampilan awal antarmuka berupa form login. Pada form login dibagi kedalam 2 (dua) kategori hak akses yaitu hak akses sebagai Kepala BAU dan hak akses Ketua Yayasan/Pimpinan (Ka. Yayasan). Form login seperti pada Gambar 2. 


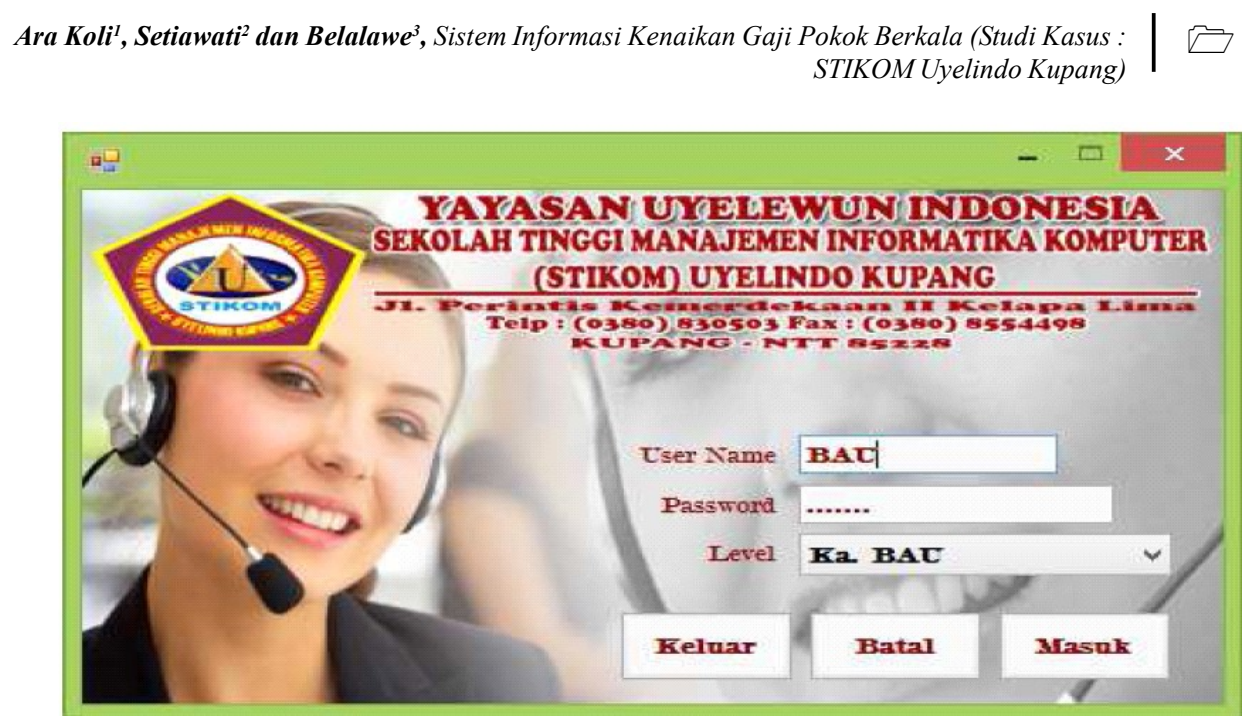

Gambar 2. Form Login

Jika pada form login terisi dengan data yang benar maka selanjutnya akan masuk pada form menu utama. Pada menu utama terdiri dari beberapa menu seperti ditunjukkan pada Gambar 3 sebagai berikut:

a. Menu Master Data merupakan menu yang berisi data jabatan struktural, jabatan fungsional dan data karyawan.

b. Menu Kenaikan Gaji Pokok Berkala untuk memasukkan data gaji berkala karyawan berdasarkan masa kerja dan tanggal masuk kerja pertama serta berdasarkan pendidikan terakhir.

c. Menu Data Tunjangan untuk memasukkan data tunjangan yang diterima oleh karyawan yang terdiri dari tunjangan struktural, fungsional, transportasi, pengabdian, kesehatan dan hari tua. d. Menu Data Potongan dan Angsuran untuk memasukkan data pinjaman karyawan baik yang pinjam ke bank atau lembaga serta data jumlah potongan setiap bulan. Selain itu ada potongan indisipliner yang merupakan potongan bagi karyawan yang terlambat masuk kerja.

a. Menu Detail Gaji Karyawan untuk memasukkan data-data gaji karyawan. Didalam data gaji karyawan terdapat informasi tentang Gaji karyawan, tunjangan karyawan, potongan indisiliner, potongan yayasan, potongan bank serta informasi gaji bersih karyawan.

b. Menu Laporan berisi laporan slip gaji per karyawan dan laporan kenaikan gaji berkala.

c. Menu Rekapitulasi Penggajian berisi laporan gaji secara keseluruhan.

d. Menu Bantuan Program berisi panduan petunjuk menggunakan program.

e. Menu Contact Yayasan berisi data alamat dan telpon kantor yayasan. 


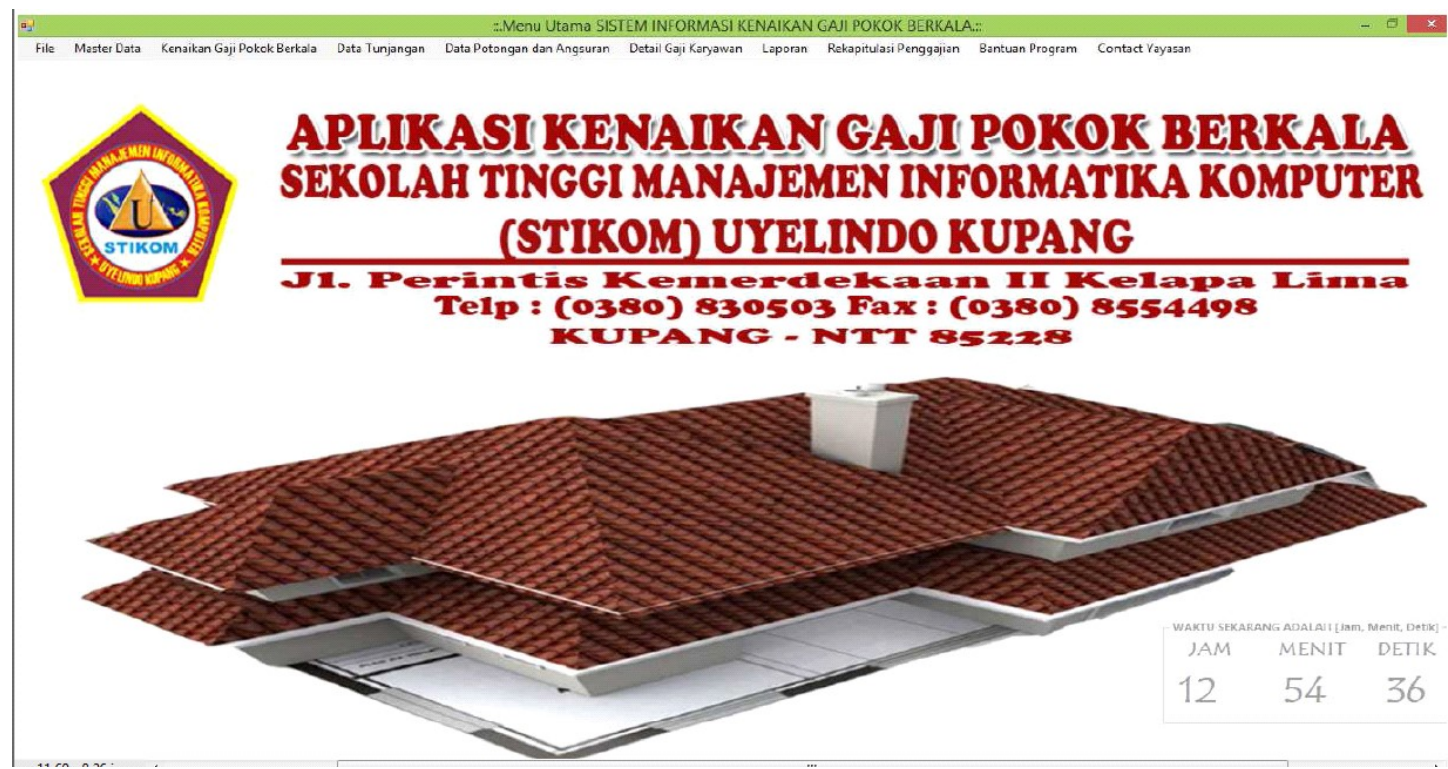

Gambar 3. Menu Utama

Informasi data gaji pokok berkala dimasukkan dalam form seperti pada gambar 4. Form ini berfungsi untuk mengelola data kenaikan gaji pokok berkala. Informasi dari Data Kenaikan
Gaji Pokok berkala dapat diketahui apabila lama kerja karyawan telah mencapai 2 Tahun dan 1 Bulan.

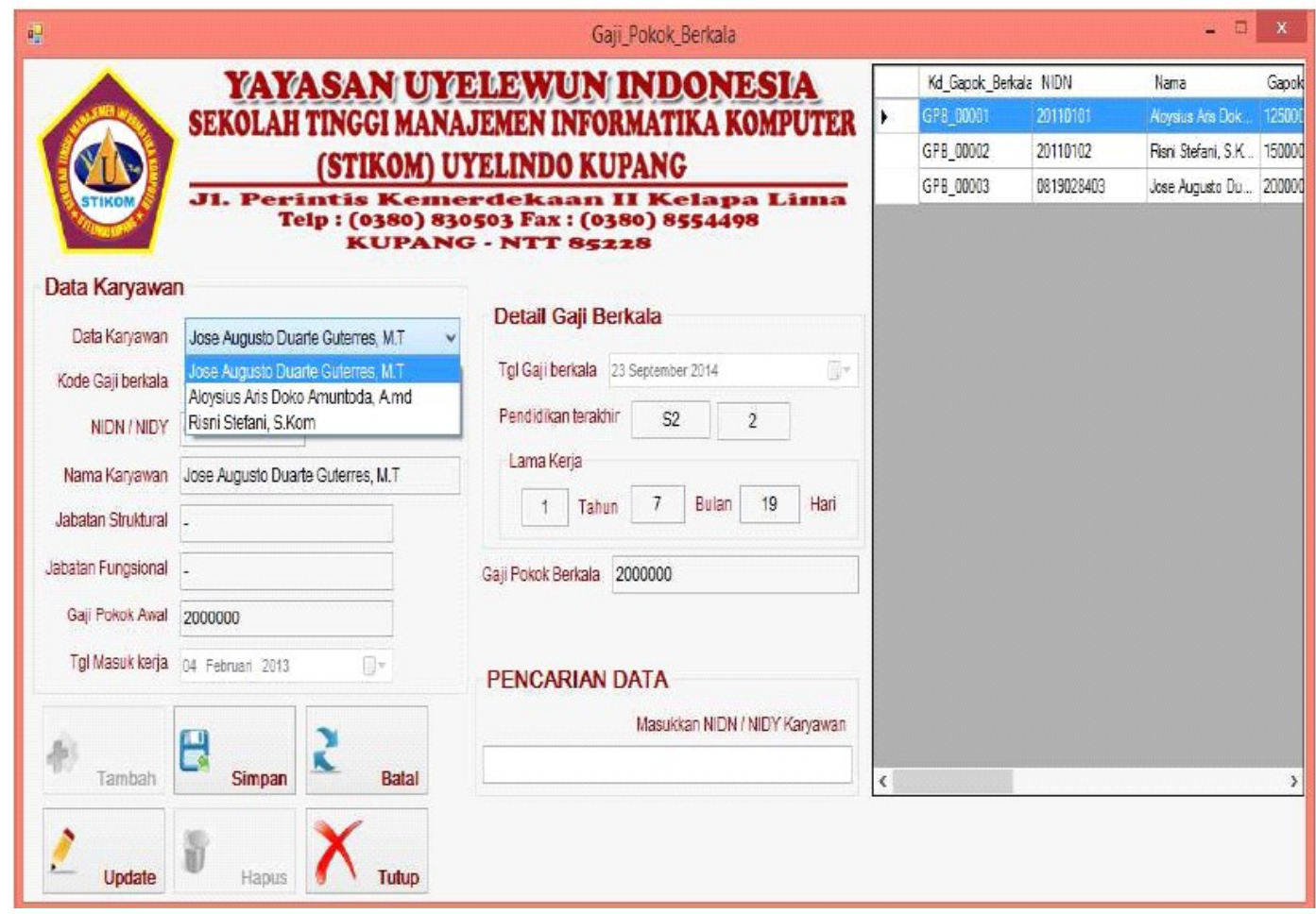

Gambar 4. Form Gaji Pokok Berkala 
Form detail penggajian seperti pada gambar 5 berfungsi untuk memasukkan data-data gaji karyawan. Didalam data gaji karyawan terdapat informasi tentang Gaji karyawan, tunjangan karyawan, potongan indisiliner, potongan yayasan, potongan bank serta informasi gaji bersih karyawan. Dari data detail gaji karyawan inilah dapat diketahui laporan penggajian.

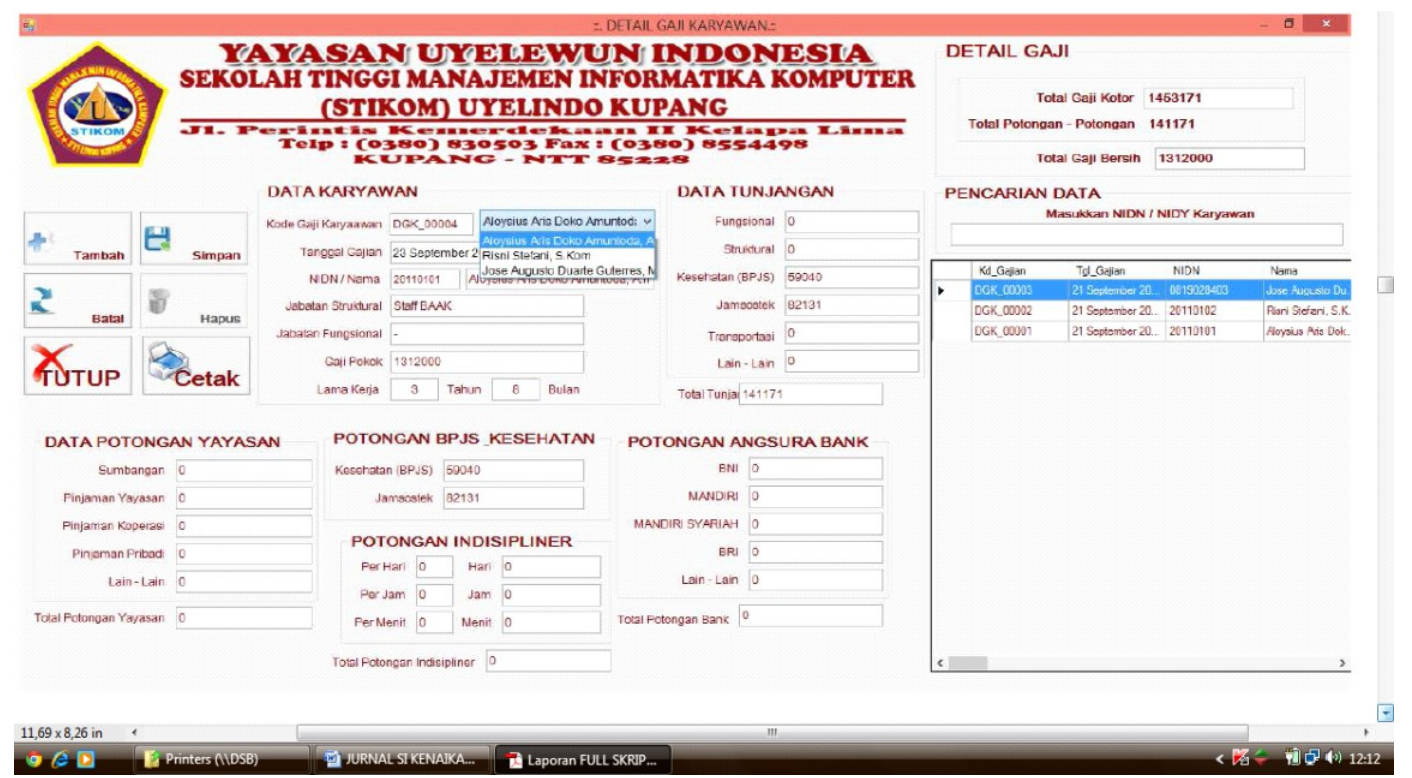

Gambar 5. Form Detail Gaji Karyawan

\section{SIMPULAN}

Berdasarkan hasil penelitian ini dapat disimpulkan bahwa sistem informasi kenaikan gaji pokok berkala pada STIKOM Uyelindo Kupang sudah sesuai dengan kebutuhan sistem yang ada pada lembaga ini. Setelah dilakukan pengujian pada sistem yang baru ini hasilnya adalah bahwa sistem mampu memberikan solusi atas permasalahan yang ada yaitu mampu memberikan informasi yang tepat tentang kenaikan gaji pokok berkala secara otomatis.

Saran yang dapat diberikan bagi peneliti lainnya untuk pengembangan sistem ini adalah:

a. Membuat sebuah trigger untuk memicu kenaikan gaji pokok berkala sehingga pada saat aplikasi ini dijalankan maka, perubahan pada gaji berkala dapat terupdate secara otomatis b.Membuat sistem secara client server yaitu menghubungan sistem penggajian ini dengan aplikasi lain yang masih berada dibawah naungan YAYASAN UYELEWUN KUPANG.

\section{DAFTAR PUSTAKA}

Giyarti, Arif. 2006. Pengembangan Sistem Informasi Penggajian Pegawai Pada Puslibang Sda Balai Sobo Yogyakarta. Skripsi. STMIK AMIKOM. Yogyakarta.

Mulyadi. 2001. Sistem Akuntansi. Edisi Ketiga, Cetakan Ketiga, Penerbit Salemba Empat, Jakarta

Pramawanti, Rani. 2003. Analisis Sistem Akuntansi Penggajian Dan Pengupahan Karyawan Pada PT. Supersonic Chemical Industry Gunungkidul. Skripsi. STMIK AMIKOM. Yogyakarta.

Rahmat M, Samik Ibrahim. 2005. Penelitian Bidang Sistem Informasi Managemen Di Indonesia (SIMDI): Quo Vadis?. Jurnal Sistem Informasi MTIUI, Vol 1(2), Oktober 2005. 